\title{
The Mackerel Fishery in the West of England.
}

\author{
By
}

\section{R. J. Ridge.}

THE mackerel fishery began off Plymouth in January, and boats from Yarmouth, Lowestoft, Newhaven, Brighton, Eastbourne, Hastings, Plymouth, together with a considerable number of Mount's Bay boats (Porthleven, Newlyn, and Mousehole) were engaged in the above fishery. Fish were found about the 13th January fifteen to twenty-five miles south-west of the Start Point, of a very fine quality, and were caught in considerable quantities for some few nights, catches from two lasts $(20,000)$ down to few hundreds per boat. Westerly and south-west winds prevailing (strong breezes), very stormy weather set in, and fishing operations were interrupted for three weeks, when the boats got to work again, meeting only with light catches for some weeks, February and March were not very successful months, easterly winds set in and continued throughout above months, and practically nothing was done till latter part of March and beginning of April, when boats fell in with fish southwest of Eddystone fifteen to twenty-five miles. There fish were not so fine in quality as those of January, and appeared to be quite distinct from the latter. Some good hauls were secured, one last (being about the largest catch) to few hundreds per boat. The fishing continued up to May, and boats did fairly well, a good average earnings was obtained; prices kept up, especially during Lent.

The spring fishing off the Lizard was practically a failure, no doubt the result of strong east winds; generally the Mount's Bay boats meet with good catches of fish during March and April from five to twelve miles south-west to west of the Lizard. In 1887 it was late in April before they were met with in any considerable quantities, but this year (1888) very few indeed were secured on this ground.

A few nights' good fishing were secured twenty-five to thirty miles south to south-south-east of Lizard, and the quality very clearly indicated them to be of the usual Lizard spring shoal.

The commencement of May Bay-boats* shifted nets (took on

* The fishing boats belonging to Mount's Bay are usually spoken of in the West of England as the "Bay-boats."-ED. 
board a large mesh net), and as usual went to the ground off Scilly. During first part of the month very unsettled weather set in and very little could be done. The month, however, closed with a very good fishing and some very fine hauls were taken and the quantity excellent.

During May the greater part of the Lowestoft boats continued to find fish in considerable quantities forty miles south of Mount's Bay, and the quality also was very fair though not equal to those from the Scilly ground.

The fishing during June off Scilly was fairly well maintained, and mackerel kept in capital condition, maintaining a flavour somewhat superior to ordinary June fish.

The season held on till the very end of the above month, and even several boats continued fishing the whole of July, getting catches of 1000 to 200 per boat.

Owing to prevalence of light winds Scilly fishing was closed in June, and the fishing during July was prosecuted off Mount's Bay twelve to twenty miles.

September.-Bay-boats met with fish again off the Bay in fair quantities, the quality being most excellent.

December.-The fleet fitted out again for the mackerel fishing off Plymouth, and the first that were taken was on the night of Friday, December 7th, nine miles south-west Start, by the "Mizpah," of Porthleven, 1000 fish being her catch.

Tuesday, 11th December, five boats landed from same ground $3000,2900,2600,500$, and 300 respectively, quality most excellent.

13th inst., catches from 2700 down to 100 per boat were landed.

During the week the very bright moonlight has somewhat been against good fishing.

The year's fishing has been above the average during the last nine years financially for the fishermen, as prices have been rather higher on the whole.* Quantity a little below. Quality very satisfactory.

* The high prices of mackerel, and consequent high returns to the West of England fishermen, are due to the failure of the Kinsale mackerel fishery, which has been unprecedentedly bad during the past year. 